\title{
伸縮性と耐久性を有する超薄膜有機太陽電池の特徵と発電性能
}

\author{
福田 憲二郎 ${ }^{1}$, 染谷 隆夫 ${ }^{1,2}$ \\ '理化学研究所 ( ₹351-0198 埼玉県和光市広沢2-1) \\ ${ }^{2}$ 東京大学 ( $\overline{1} 113-8656$ 東京都文京区本郷7-3-1)
}

\section{Ultra-Thin Organic Solar Cells with Excellent Stretchability and Durability}

\author{
Kenjiro FUKUDA ${ }^{1}$ and Takao SOMEYA ${ }^{1,2}$ \\ 'RIKEN, 2-1 Hirosawa, Wako, Saitama, 351-0198 \\ ${ }^{2}$ The University of Tokyo, 7-3-1 Hongo, Bunkyo, Tokyo, 113-8656
}

(Received December 4, 2018)

\begin{abstract}
In recent years, highly flexible solar cells have been gathering great interest as a power source for operating wearable and/or on-skin electronic devices which are necessary technologies for the Internet of things (IoT) society. By adapting such flexible solar cells, wearable and on-skin devices can be free from the troubles of replacement of batteries and contact problems of external wirings. In this paper, our approaches for ultra-thin organic solar cells will be introduced with three important keywords, namely "high power conversion efficiencies", "strethchability/flexibility" and "robustness against the environmental conditions".
\end{abstract}

Key Words: Organic solar cells, Flexibility, Stretchability, Conformability

1. はじめに

近年, 柔軟性の高い太陽電池は，もののインターネッ ト (IoT) 社会を支えるウェアラブルエレクトロニクスや 皮膚直接貼り付け型デバイスなどを駆動するための電源 として大きな期待を集めている ${ }^{1,2)}$. 柔軟性の高い太陽 電池を衣服などへ貼り付けることで，バッテリーの交 換・配線の問題などの煩わしさから開放されたウェアラ プルデバイスが実現可能になる.

本稿では, 上記ウェアラプルエレクトロニクス用の新 しい太陽電池を実現するために重要3つのキーワード, すなわち「高いエネルギー変換効率」,「伸縮性・柔軟 性」、「環境に対する耐久性」，を実現するための著者ら のアプローチを紹介する.

\section{2. 機械的安定性の改善}

\section{1 曲げ剛性}

衣服や肌などの複雑な表面上にエレクトロニクスを実 装させる際に，「柔らかさ」が非常に重要なターダットと なる.この「柔らかさ」を決定する重要なパラメーターと して, 曲げ剛性(Flexural rigidity)がある.フィルムなど 平たい板材を想定した際のFlexural rigidityの定義は下記 の通りである ${ }^{3)}$.

$$
D=\frac{E t^{3}}{12\left(1-v^{2}\right)}
$$

ここで, $E$ : ヤング率, $t$ :フィルムの膜厚, $v$ : ポアソン比 である.この数式で非常に重要なことは，フィルムの膜 厚を小さくすることで, Flexural rigidityも小さくなり, その結果フィルムが曲がりやすくなるということであ る. 人体の組織で例えば皮虑のヤング率は $100 \mathrm{kPa}$ 程度 であるのに対し、フレキシブル電子デバイスに使用され る、ポリエチレンテレフタレート(PET)やポリエチレン ナフタレート $(\mathrm{PEN})$ を代表とするプラスチックフィルム は1 GPaのオーダーであり，両者には $10^{4}$ 以上の非常に大 きな差が存在する．このようなヤング率の著しく異なる 物質同士でも，フィルムの膜厚を極端に薄くすることで 追従しやすい状態を実現することが可能となる. 実際, 厚さ $2.5 \mu \mathrm{m}$ 程度の非常に薄いエレクトロニクスを利用す ることで, 脳のような深いシワを持つ・柔らかい対象の 表面に密着することが可能となるということが報告され ている4).

\section{2 歪み中間位置}

フレキシブルエレクトロニクスの機械的柔軟性を向上 させる重要なアイデアに「素子をひずみ中間位置 (Neutral strain position)に配置する」というものがある。ひずみ中 
間位置とは，曲げひずみをフィルムに印加した際に，圧 縮ひずみと引張ひずみがお互いにキャンセルしあって， 歪がゼロになる面のことを指す5). $n$ 枚のフィルムレイ ヤからなる多層構造のひずみ中間位置は以下の式によっ て与えられる

$$
b=\frac{\sum_{i=1}^{n} E_{i} t_{i}\left[\sum_{j=1}^{i} t_{j}-\frac{t_{i}}{2}\right]}{\sum_{i=1}^{n} E_{i} t_{i}}
$$

この式を利用し，ひす゚み中間位置に電子デバイスを配置 することで, 有機半導体を用いたデバイスで限界曲げ半 径10 $\mu \mathrm{m}$ 以下という「くしゃくしゃにしても壊れない」エ レクトロニクスが可能となる7).

\section{3 伸縮性の付与}

伸縮性を有する材料だけを用いてエレクトロニクスを 形成することで「本質的に」伸縮性のあるエレクトロニク スは実現可能であり，トランジスタなどでは実際の報告 例もある ${ }^{8)}$. しかし太陽電池を構成する全ての層を本質 的に伸縮性のある材料のみを使用する，というアプロー チでは, エネルギー変換効率といったデパイスの性能や 安定性を犠牲にしてしまう。代替的なアプローチとして は構造の工夫による伸縮性の付与であり，代表的なもの が非常に薄いエレクトロニクスフィルムをゴムに貼り付 けたバックリング構造である. 予め引張ひずみを加えた ゴムに厚さ数 $\mu \mathrm{m}$ のィルムを載せ、ゴムのひす゚みを緩 和させた場合, アコーディオンのようなバックリング構 造がフィルムに形成される。この際フィルムは折り畳ま れたような形になり，局所的な曲率半径は10 $\mu \mathrm{m}$ を下回 る. 前節で述べたように，非常に薄いフィルムを用い， エレクトロニクスをひずみ中間位置に配置した場合，限 界曲げ半径は $10 \mu \mathrm{m}$ 以下となるため, このような極端な 条件であっても有機エレクトロニクスは壊れることがな いため，「伸縮性」をエレクトロニクスに付与することも 可能となる.

\section{3. 超薄型有機太陽電池の効率向上と安定性改善}

\section{1 テ゚パイス構造及び材料}

我々の超薄型有機太陽電池の断面構造図をFig. 1に示 す. 最大の特徵は厚さ $1 \mu \mathrm{m}$ 程度の高分子フィルムを基 板として使用していることである. 基板フィルムを支持 体となるガラス上に平滑に形成する技術を確立すること で，通常の有機太陽電池とほほ同様のプロセスを使用し

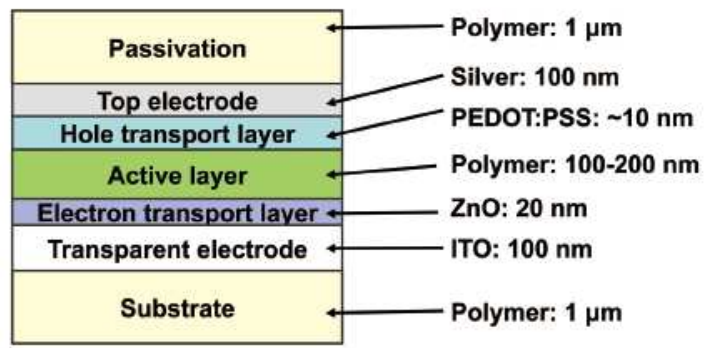

Fig. 1 Schematic illustration for an ultra-thin organic solar cell.
て素子を形成することが可能となった．また，封止膜に も基板と同様，厚さ $1 \mu \mathrm{m}$ の高分子材料を使用しており， 全体としての素子膜厚は約 $3 \mu \mathrm{m}$ である. 基板材料に使 用しているポリマーはパリレン(KISCO, diX-SR)や， 透明ポリイミド(三井化学, ECRIOS $\left.{ }^{\oplus}\right)$ である.

\section{2 エネルギー変換効率}

超薄型有機太陽電池のエネルギー変換効率(Power conversion efficiency: PCE) を向上させるプロセスとして は，基本的にはガラス基板を用いた時と同様に，活性層 材料や電荷注入層の改良が重要なポイントとなる。それ に加えて, 我々は基板の耐熱性がPCE向上に重要な役割 を担っているということを見出した. 例えば基板にパリ レンを用い, 活性層材料に加熱しながらのスピンコート を必要とする quaterthiopheneとnaphtho [1,2-c:5,6-c'] bis $[1,2,5]$ thiadiazoleを用いたドナー・アクセプター型ブレ ンドポリマー(PNTz4T $)^{9)}$ を使用した際の特性は，ガラ ス基板と超薄型基板とで大きな差が現れた(Fig. 2(a)). ガラス基板上では最大PCEは9.8\%であったのに対し，超 薄型基板上では7.9\%の值しか得られなかった ${ }^{10)}$ 。一方， 基板に耐熱性に優れる透明ポリイミドを使用し，活性層 に耐熱性に優れ，かつ室温でのスピンコート成膜が可能 なpoly [4,8-bis (5-(2-ethylhexyl) thiophen-2-yl) benzo [1,2-b;4,5-b'] dithiophene -2,6-diyl-alt- (4-octy1-3-
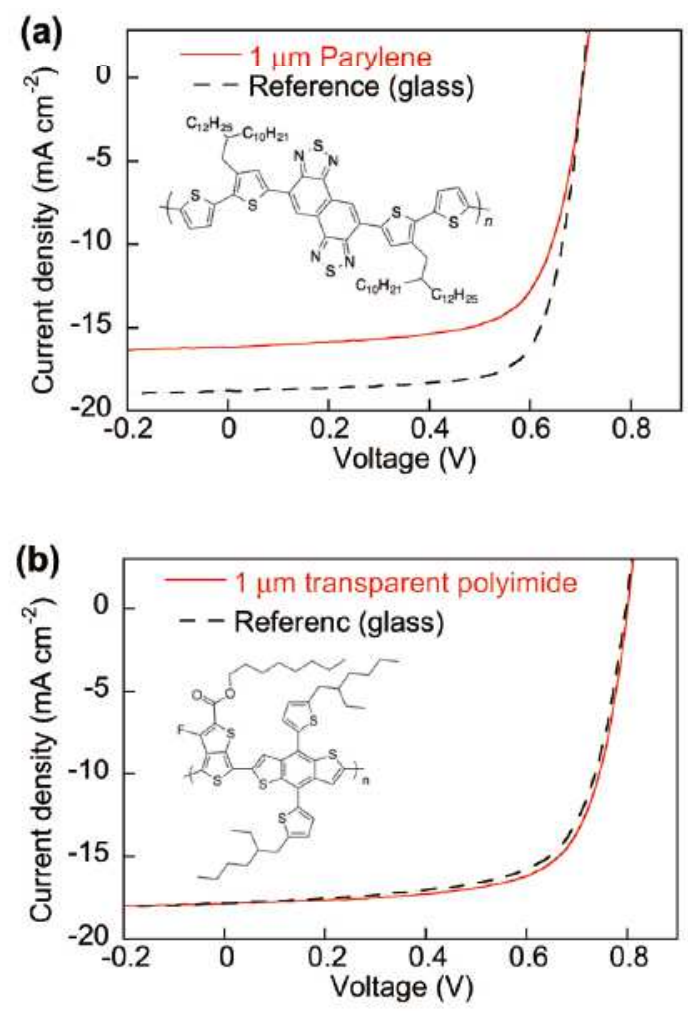

Fig. 2 J-V characteristics of (a) PNTz4T solar-cells on parylene substrate, and (b) PBDTTT-OFT solar cells on transparent polyimide substrate. Dashed lines represent reference cell performances on rigid glass substrates. Insets are chemical structures of active layers used. 
fluorothieno [3,4-b] thiophene)-2-carboxylate-2-6-diyl] (PBDTTT-OFT) を使用すると，ガラス基板上で $9.7 \%$, 超 薄型太陽電池で10.0\%というPCEをそれぞれ示し, 超薄 型有機太陽電池がガラス基板上に匹敵する性能を達成す ることに成功しだ1).

基板・活性層材料の違いがPCEに与える影響について はまだ確証のあるデータは取れていないが, 一つの大き な理由に, 加熱によるプラスチックフィルムの変形が挙げ られると考えられる. パリレンは比較的ガラス転移点が $100^{\circ} \mathrm{C}$ 以下と予想される結果が過去に報告されており ${ }^{12)}$, 加熱を伴う有機太陽電池のプロセスで基板が流動的にな ると基板上に形成した各層が変形してしまうため，ガラ スと同等の程度の性能を達成することが困難である。一 方で耐熱性の高い基板を利用し室温で活性層を形成する ことで，熱による上記の劣化要因を排除し，ガラス基板 と同等の性能を達成することが可能となった.

\section{3 伸縮性と水安定性}

2.3節で述べた引張ひずみを印加したコムに超薄型有 機太陽電池を載せて伸縮性を付与するというアプローチ を更に改良し，2枚のゴムでサンドイッチするというア イデアを着想した(Fig. 3).これによって伸縮性と水安
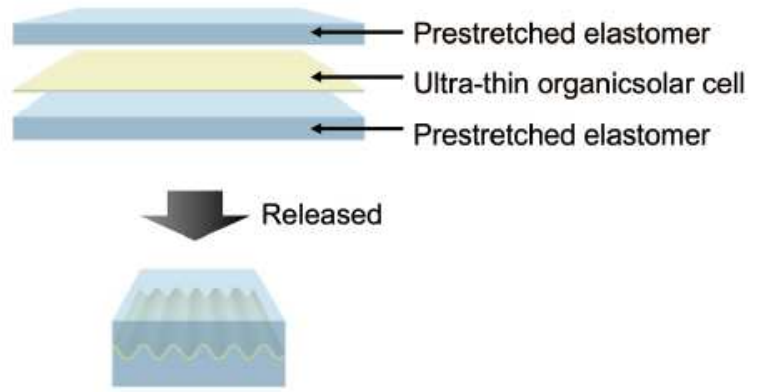

Fig. 3 Schematic illustration of double-elastomer coated stretchable solar cells. (a)

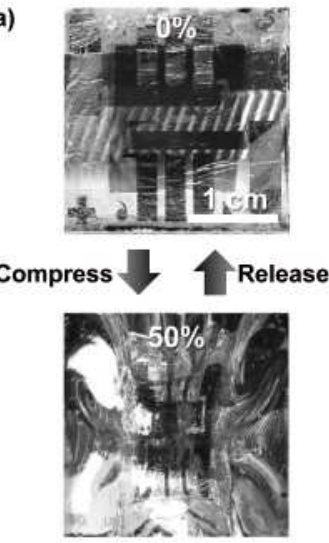

(b) Accunulated water exposed time (min)

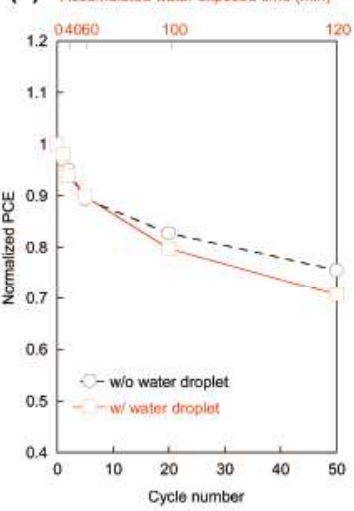

Fig. 4 (a) Picture sequence of the formation of double-side-coated OPVs when the elastomer is relaxed. (b) Cyclic compression test with water exposure. The OPVs are exposed to water between each compression cycle. Open circles and open squares represent the change of PCE without and with water exposure, respectively.
定性を同時に満たす有機太陽電池が実現された，実際， $50 \%$ 伸縮サイクル試験を水滴の有無によって比較し， PCEの変化が水滴の有無にほとんど影響を受けないこと を見出した(Fig. 4).これらの知見は超薄型有機太陽電 池が「洗濯可能」な安定性を持てることを示唆しており, 特にウェアラプルデパイス用途に非常に重要な結果であ る.

\section{4 熱安定性}

3.2節で述べた透明ポリイミドを基板として使用し, PBDTTT-OFTを活性層に利用した超薄型有機太陽電池 は, 耐熱性に優れているというもう一つの重要な結果を

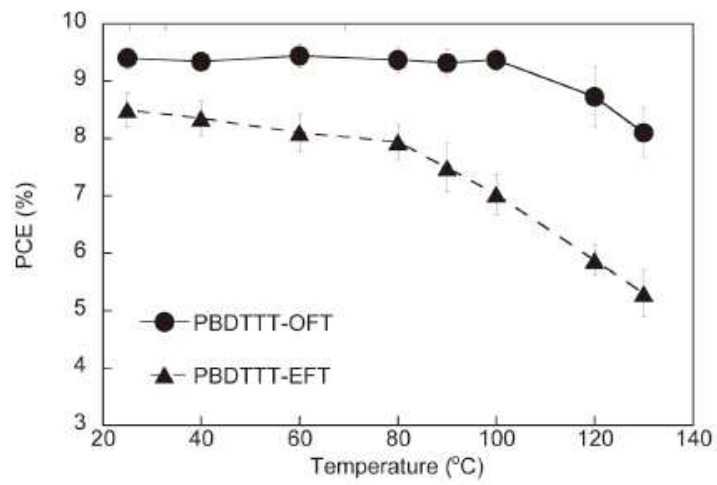

Fig. 5 Short-time thermal stability comparison between OPVs with PBDTTT-OFT:PC71BM and PBDTTT-EFT:PC71BM blends, with the same device structure and heat-treated in ambient air.
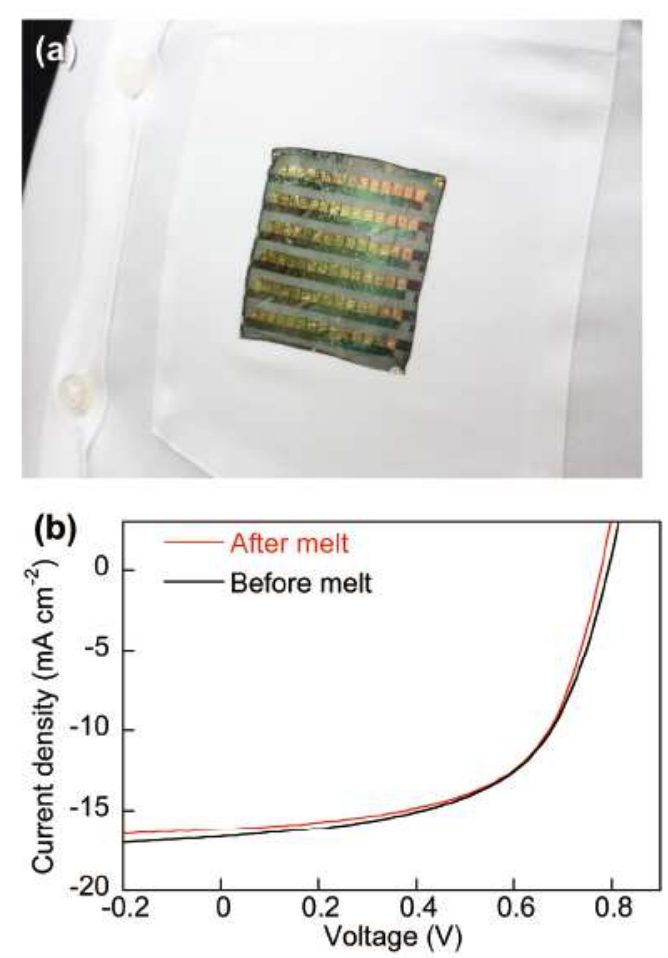

Fig. 6 (a) Photograph of an ultra-thin organic solar cell module adhered on textile after the instant hotmelt process. (b) J-V characteristics of the solar cell before and after the hot-melt process, showing no electrical degradation. 
示した.これは耐熱性の高い基板を利用したことによる 基板の熱膨張の抑制と，活性層自身の優れた耐熱性の効 果によるものである。実際に，PBDTTT-OFTとよく似た 構造を有する poly [4,8-bis (5-(2-ethylhexyl) thiophen-2-yl) benzo [1,2-b;4,5-b'] dithiophene-2,6-diyl- alt-(4(2-ethylhexyl)-3-fluorothieno[3,4-b]thiophene) -2-carboxylate-2-6-diyl](PBDTTT-EFT) を比較として使用 し. 加熱後のPCEの変化を測定したところ(Fig. 5)， PBDTTT-EFTを使用した太陽電池は $100^{\circ} \mathrm{C} の$ 加熱後に PCEが8.5\%から7.0\%に低下 (減少率 $18 \%$ ) したのに対し， PBDTTT-OFTを使用した太陽電池は同じ条件でPCEが $9.4 \%$ を保持した(隇少率 $1 \%$ 以下)。このように $100^{\circ} \mathrm{C}$ 程度 の加熱によっても全く特性が変化しない特徴によって, ホットメルトによる衣服貼付けプロセスが実現可能とな る(Fig. 6). ポリウレタンをメルトフィルムとして使用 し, $120^{\circ} \mathrm{C}, 30$ 秒のホットメルト条件で超薄型太陽電池 をポリエステルまたは綿の布地に貼りつけたあとでも

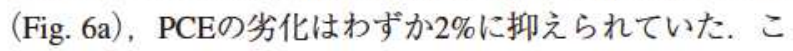
れらの結果は我々の超薄型太陽電池が衣服上で集積化さ れ, ウェアラブルエレクトロニクス用の電源として十分 に使用可能であることを示している.

\section{4. まとめ}

超薄型有機太陽電池が今後, 工業化されるためには, 効率の向上は重要なアプローチである. 現在, ガラス基 板上での有機太陽電池の性能は14\%を超えており ${ }^{13)}$ ，ま た鉛を用いないペロブスカイト太陽電池のPCEが9\%を 超えるなど ${ }^{14)}$ ，材料の持つポテンシャルは年々着実に進 歩している. 超薄型の基板を使用して, これらの最先端 の值にどこまで近づけることができるかが、今後の重要 なアプローチとなる. 一方, 基板や封止膜を薄くして柔 軟性を上げることと安定性の向上はトレードオフ関係に なっており, 全体の厚さを薄くしながらいかに長期間安 定的に連続駆動をするような素子を実現するかが, 単純 な効率向上よりも重要な課題として存在する.

これらの課題を一つ一つ克服することで, 将来のIoT 向け電源としての超薄型太陽電池の実現への道筋が少し す゚つ切り拓けていくであろう.
本研究の一部はJSTさきがけ(課題番号JPMJPR1428), JST ERATO(課題番号JPMJER1105)の支援を受けて行わ れた。透明ポリイミドは三井化学株式会社より, PBDTTT-OFTは東レ株式会社よりそれぞれ提供を受けた ものである.

\section{参考文献}

1) M. Kaltenbrunner, G. Adam, E.D. Głowacki, M. Drack, R. Schwödiauer, L. Leonat, D. H. Apaydin, H. Groiss, M. C. Scharber, M.S. White, et al: Nat. Mater. 14, 1032 (2015).

2) M. Kaltenbrunner, M. S. White, E. D. Głowacki, T. Sekitani, T. Someya, N. S. Sariciftci, and S. Bauer: Nat. Commun. 3, 770 (2012).

3) L. D. Landau and E. M. Lifshitz: Theory of Elasticity, Vol. 7 (3rd ed.). Butterworth-Heinemann. p. 42 (1986).

4) D.-H. Kim, J. Viventi, J. J. Amsden, J. Xiao, L. Vigeland, Y.-S. Kim, J. A. Blanco, B. Panilaitis, E. S. Frechette, D. Contreras, et al: Nat. Mater. 9 (2010) 511.

5) T. Sekitani, U. Zschieschang, H. Klauk, and T. Someya: Nat. Mater. 9 (2010) 1015.

6) D.-H. Kim, J.-H. Ahn, W. M. Choi, H.-S. Kim, T.-H. Kim, J. Song, Y. Y. Huang, Z. Liu, C. Lu, and J. A. Rogers: Science. 320 (2008) 507.

7) M. Kaltenbrunner, T. Sekitani, J. Reeder, T. Yokota, K. Kuribara, T. Tokuhara, M. Drack, R. Schwödiauer, I. Graz, S. Bauer-Gogonea, et al: Nature 499 (2013) 458.

8) S. Wang, J. Xu, W. Wang, G.-J. N. Wang, R. Rastak, F. MolinaLopez, J. W. Chung, S. Niu, V. R. Feig, J. Lopez, et al: Nature 555 (2018) 83.

9) V. Vohra, K. Kawashima, T. Kakara, T. Koganezawa, I. Osaka, K. Takimiya, and H. Murata: Nat. Photonics 9 (2015) 403.

10) H. Jinno, K. Fukuda, X. Xu, S. Park, Y. Suzuki, M. Koizumi, T. Yokota, I. Osaka, K. Takimiya, and T. Someya: Nat. Energy 2 (2017) 780.

11) X. Xu, K. Fukuda, A. Karki, S. Park, H. Kimura, H. Jinno, N. Watanabe, S. Yamamoto, S. Shimomura, D. Kitazawa, et al: Proc. Natl. Acad. Sci. 115 (2018) 4589.

12) K. Fukuda, T. Suzuki, D. Kumaki, and S. Tokito: Phys. Status Solidi Appl. Mater. Sci. 209 (2012) 2073.

13) S. Zhang, Y. Qin, J. Zhu, and J. Hou: Adv. Mater. 30 (2018) 1800868.

14) F. Wang, X. Jiang, H. Chen, Y. Shang, H. Liu, J. Wei, W. Zhou, H. He, W. Liu, and Z. Ning: Joule doi: 10.1016/j.joule.2018.09.012. 